\title{
Higher Level of Cognitive Reserve Reduces the Risk of Cognitive Difficulties in Healthy Adults
}

\author{
Ewa Małgorzata Szepietowska \\ Maria Curie-Sklodowska University, Institute of Psychology, Department of \\ Clinical Psychology and Neuropsychology, Lublin, Poland
}

Anna Kuzaka

Provincial Specialist Hospital, Biała Podlaska, Poland

\begin{abstract}
The study was designed to investigate whether a level of cognitive reserve (CR) is associated with a level of cognitive competences in adults. Evidence from numerous earlier studies suggests that high CR, defined as previously acquired knowledge and experience, plays a protective role with respect to cognitive capacities in adults and senior citizens. Hence, it was hypothesised that a lower CR would predict lower cognitive capacities. The study involved 120 Polish healthy adults (75 women and $45 \mathrm{men})$ ranging in age from 40 to 85 years $(M=57.42 ; S D=10.48)$. The applied CR index took into account formal education level, involvement in social, occupational and physical activity, and level of social support. The recorded data also included depression level (Beck Depression Inventory, BDI II) and cardiovascular status (hypertension: yes / no). The subjects' current cognitive competences were assessed using Montreal Cognitive Assessment test (MoCA), Wechsler Adult Intelligence Scale (WAIS) subtests, verbal fluency tests and Dysexecutive Questionnaire, self-report version (DEX-S). Based on the subjects' scores in cognitive tests, a cluster analysis was performed, and the participants were divided into two groups presenting lower cognitive level (LCL) and higher cognitive level (HCL). The LCL subjects were older than HCL and they had higher level of depression and lower CR. In order to determine whether lower level of $\mathrm{CR}$ is related to lower level of cognitive abilities in the adults, logistic regression analysis was carried out, also taking into account age, cardiovascular status and depression level. It was shown that the higher level of CR reduced the risk of cognitive deficits. Older age corresponds to poorer cognitive function. The findings showed no interaction between CR and age. Depression and health status did not predict level of cognitive abilities. The current findings are consistent with results of earlier studies: higher level of CR may be associated with a lower risk of cognitive deficits and age is a $\mathrm{CR}$-independent variable that affects cognitive performance: the risk of cognitive decline increases with age. These findings are discussed with reference to models and CR indices.
\end{abstract}

Keywords: cognitive reserve, adults, cognitive functioning

Ewa Małgorzata Szepietowska, Department of Clinical Psychology and Neuropsychology, Institute of Psychology, Maria Curie-Sklodowska University, 20080 Lublin, Litewski Square 5, Lublin, Poland. E-mail: ewa.szepietowska@poczta. umcs. lublin.pl 


\section{Introduction}

The phenomenon of double ageing can be observed in the populations of many European countries, including Poland (Długosz, 2011). This is a result of numerous factors, such as the decrease in the number of young people and fertility rate, increased longevity and higher percentage of senior citizens (60+), including people aged 80+ (WHO, 2015). Ageing is associated with an increasing risk of dementia. Projections related to dementia epidemiology show that the number of those affected may double during 2030-2050 (Prince et al., 2013). Due to this, more and more studies focus on ways to prevent cognitive decline in older adults. They emphasize the role of cognitive reserve (CR) and the fact that it can be improved even in adulthood (Cheng, 2016; Middleton \& Yaffe, 2009; Thow et al., 2018). The role of $\mathrm{CR}$ is to sustain coping abilities, despite the brain changes associated with acquired disorders of the central nervous system (CNS) or linked to the ageing process (Stern, 2002). The construct of CR explains situations when, contrary to expectations, cognitive performance is disrupted only to a small degree or is unaffected (Blessed, Tomlinson, \& Roth, 1968; Katzman et al., 1988; Opdebeeck, Martyr, \& Clare, 2016; Scarmeas \& Stern, 2003; Singh-Manoux et al., 2011; Stern, 2012). Higher CR may attenuate effects of age-associated cognitive decline (Zihl, Fink, Pargent, Ziegler, \& Bühner, 2014), or modify progression of dementia (Daffner, 2010; Le Carret et al., 2005; Tucker-Drob, Johnson, \& Jones, 2009). Effects of higher CR in healthy adults and in seniors are observed in better performance related to attention, psychomotor speed, verbal memory, and executive functions, and in lower self-reported cognitive difficulties (Frankenmolen, Fasotti, Kessels, \& Oosterman, 2018; Roldán-Tapia, García, Cánovas, \& León, 2012), whereas lower level of CR is associated with deficits of attention, memory and poor global cognitive functioning (Corral, Rodriguez, Amenedo, Sanchez, \& Diaz, 2006).

The level of CR results from knowledge and skills acquired over the lifespan. Higher CR is determined by higher education level, greater intensity and quality of physical, occupational, social and cognitive activity (Nucci, Mapelli, \& Mondini, 2012; Roldán-Tapia, Cánovas, León, \& García-Garcia, 2017; Steffener \& Stern, 2012; Stern, 2003, 2009; Tucker \& Stern, 2011), multilingualism (Schweizer, Ware, Fischer, Craik, \& Bialystok, 2012), good social support (Amieva et al., 2010), and intellectual involvement (Adam, Bonsang, Grotz, \& Perelman, 2013; Mella, Grob, Döll, Ghisletta, \& de Ribaupierre, 2017). CR is adversely affected by interrelated factors such as depression (Butters et al., 2008), poor education, loneliness and sense of isolation, lack of social support (Di Napoli, Wu, \& Scogin, 2014), lack of both cognitive stimulation and physical activity as well as metabolic syndromes (Middleton \& Yaffe, 2009).

Higher CR promotes development of better parameters of brain reserve (BR), i.e., selected or specialised functional networks which enable more effective and cognitively less engaging information processing (Marques et al., 2016; Steffener \& 
Stern, 2012; Stern, 2002, 2003, 2009). Therefore, cognitive difficulties can be effectively compensated even if a certain threshold of brain pathology is exceeded.

Higher CR is not only conducive to adults' ability to maintain good cognitive efficiency later in life, but it also decreases the risk of dementia. It reduces the risk of Alzheimer's disease (AD) by approximately $50 \%$ in APOE $\varepsilon 4$ gene carriers, although $\varepsilon 4$ as an independent factor increases such a risk by approximately $150 \%$. On the other hand, APOE\&2 genotype in interaction with higher CR plays a protective role for cognitive functioning (Pettigrew et al., 2013). Similar links between genotype, CR and progressing symptoms of dementia (Placek et al., 2016) were reported in genetically determined (20-50 \% of FTD cases) familial frontotemporal dementia (fFTD) (Olszewska, Lonergan, Fallon, \& Lynch, 2016).

Contrary to the reports on the protective role of high CR, some studies showed the opposite results (León, García-García, \& Roldán-Tapia, 2014). As an example, Serra et al. (2015) demonstrated that higher CR did not protect subjects with mild cognitive impairment (MCI) against the development of AD. Similar findings were reported by Andel, Vigen, Mack, Clark, \& Gatz (2006) and Soldan et al. (2017). Singh-Manoux et al. (2011) observed more severe cognitive deterioration in individuals with higher professional status. Current data suggest that assessment of CR-related effects in cognitive competences at later stages of life should account for various resources related to life history, e.g., living conditions, previous and existing CNS disorders, drugs (Clare et al., 2017), demographic factors, ethnicity and migration (Mondini et al., 2014).

This ambiguity of the findings may be linked to the lack of consistent definitions, models, and methods applied to measure $\mathrm{CR}$ and interaction of factors forming CR (Jones et al., 2011). For instance, higher socioeconomic status (generally) goes with higher education (Oakes \& Rossi, 2003), and greater awareness of disease risks as well as increased attention to one's health. Poorer education tends to be associated with unhealthy lifestyles, and consequently with a higher degree of brain pathology and cognitive deficits (Farfel et al., 2013). Excessive engagement in professional activity may lead to sleep deficiency and stress, which adversely affect development of CR; however, the advancement of professional competences contributes to higher CR (Adam et al., 2013). Furthermore, other factors, related or unrelated to $\mathrm{CR}$, determine cognitive functioning at advanced age. There is a significant association between gender and the trajectory of this process; men present cognitive deficits earlier than women, due to greater likelihood of metabolic disorders and addictions in male populations (Zaninotto, Batty, Allerhand, \& Deary, 2018), yet symptoms of dementia or conversion of MCI into AD occur earlier in women (Laws, Irvine, \& Gale, 2016). Gender also significantly affected the CR (Nucci et al., 2012): men had a higher CR than women. Importantly, the ageing process is also affected by CR developed starting from the early stages of life; disparities in these resources explain heterogeneity of cognitive abilities even in young adults (aged 20-30 years) (Zihl et al., 2014). Given this, researchers have 
postulated various ways of enhancing CR during middle and late adulthood because diverse activities taken up at that time play a protective role for cognitive functions later in life (Blondell, Hammersley-Mather, \& Veerman, 2014; Clare et al., 2017; Ferreira et al., 2017).

The methods applied to examine relationships between CR and cognitive functions may also explain the inconsistent findings (Grotz, Seron, Van Wissen, \& Adam, 2017; Szepietowska, 2019). Generally, CR level is measured using self-report techniques (Nucci et al., 2012; Rami et al., 2011). A subjective rating of one's current and past situation depends on the interaction of a number of factors: cognitive condition, depression intensity, age, gender, and neurological determinants (Grotz et al., 2017) and is affected by the structure of the self-report tool (Knäuper et al., 2016).

Two purposes were defined for the current study, taking into account the earlier findings. The main purpose was to investigate whether the level of CR, intensity of depression, age, and health status could be recognised as predictors of cognitive competences in adults. It was hypothesised that lower CR would significantly predict lower level of cognitive functions. In view of the evidence reported in the literature and showing relations between CR and health status, age, gender and depression intensity, the study was additionally designed to further examine these relations. It was anticipated that there would be correlations between CR and depression intensity, as well as between CR and age, and that CR would be differentiated by gender and health status.

\section{Method}

\section{Participants}

Polish adults aged $40-85$ years, were invited to take part in the study. Eligibility criteria included: written consent as well as health and cognitive status required for active participation in the study. The subjects were excluded if they had a diagnosis of dementia, psychiatric diseases, addictions, and chronic somatic disorders. The relevant data were obtained from medical records, from the participants and their relatives. The analyses took into account data of 120 subjects, ranging in age from 40 to 84 years $(M=57.42 ; S D=10.48 ; M e=54.0)$. The study group predominantly comprised women $(62.5 \%)$, married people ( $88.3 \%)$, employed individuals $(65 \%)$, people with hypertension $(60 \%)$ pharmacologically controlled, and people with secondary education $(53.3 \%)$. The participants differed significantly in terms of years of education (range from 4 to $27 ; M=13.7 ; S D=4.26 ; M e=12.0$ ). 


\section{Questionnaires and Cognitive Tests}

The following measures were used:

Questionnaire related to demographic data and health status included past and present medical conditions and their types.

A modified version of the Cognitive Reserve Index questionnaire (CRIq) (Nucci et al., 2012) comprises data related to education (years of education and level of education), working activity, and leisure time activity. The modified version used in this study includes statements relating to the present economic status, physical activity (in childhood and adolescence and after 18 years of age), community involvement (voluntary work for relatives and social organisations, etc. in childhood and adolescence and after 18 years of age), and current self-reliance in daily life. The participants were asked to choose items which, in their opinion, most accurately described their activity. The rating was expressed on a scale, from 0 to 4 points, whereby: 0 score reflected no activity or low level of activity in a given area (once in 10 years), extremely low economic status and necessity to seek social support in daily life; 1 point reflected very low frequency of activity (once in a few years), poor economic status and necessity to seek social support in some situations of everyday life; 2 points reflected occasional activity (once a year), satisfactory economic status and an occasional need for social support; 3 points reflected activity performed at least once a month, good economic status, significant degree of self-reliance and no need for social support; 4 points reflected activity performed systematically, i.e., at least once a week, very good economic status and complete self-reliance. Higher score (maximum of 28 points) reflected greater activity. The final CR index was calculated as a total score comprising: education $(1$ point $=$ primary; 2 points $=$ secondary; 3 points $=$ higher $)$, work status $(0$ point $=$ unemployed $/$ retired, 1 point $=$ employed person); activity in various areas of life (scores in the range of 0-28 points). The theoretical results representing CR level were in the range from 1 point (minimum) to 32 points (maximum).

Cognitive functions were assessed using the following measures:

Subtests of the Polish version of Wechsler Adults Intelligence Scale (WAIS-R PL): Vocabulary, Digit Span Forward and Digit Span Backward (Brzeziński et al., 2004). Digit Span Forward subtest allows to determine efficiency of immediate (verbal) memory, Digit Span Backward subtest assesses working memory, and Vocabulary subtest assesses semantic memory and linguistic competence.

Five verbal fluency tasks (animals, verbs, words starting with the letter ' $\mathrm{K}$ ', two emotional fluency tasks - joy and fear) assessed efficiency of semantic memory and executive functions (Strauss, Sherman, \& Spreen, 2006) and for them a summarised score was calculated.

Montreal Cognitive Assessment Scale, MoCA (Nasreddine et al., 2005). MoCA is used as a screening measure for detecting cognitive deficits (e.g. MCI). MoCA 
scores range between 0 and 30; a score of 26 and over reflects a lack of cognitive difficulties.

The self-report Dysexecutive Questionnaire, DEX-S. DEX-S is a part of the test battery Behavioural Assessment of the Dysexecutive Syndrome (Wilson, Alderman, Burgess, Emslie, \& Evans, 1996). The subject rate 20 items regarding the difficulties encountered during activities involving executive functions, e.g., "I have trouble making decisions or deciding what I want to do". Ratings are given on a 5-point scale scale $(0=$ never, $4=$ very often $)$. A maximum score $(80$ points $)$ reflects high subjective executive difficulties, a low score corresponds to a lack of subjective executive difficulties.

Polish version of Beck Depression Inventory II (BDI II) for assessment of depressive mood intensity (Beck, Steer, \& Brown, 2019) consists of 21 items, divided into groups based on names of symptoms (e.g., Loss of Pleasure, Suicidal Thoughts or Wishes, Loss of Interest). The subject is asked to assess the intensity of a given symptom in the last two weeks, on a scale from 0 to 3 (e.g., Loss of Pleasure: 0 point: I get as much pleasure as I ever did from the things I enjoy; 1 point: I don't enjoy things as much as I used to; 2 points: I get very little pleasure from the things I used to enjoy; 3 points: I can't get any pleasure from the things I used to enjoy). A raw score exceeding 25 points indicates depression, and a score of more than 15 points suggests a clinically significant depressed mood.

\section{Procedure}

The study was approved by the University Research Ethics Committee (no. 13/2018). The study procedure is consistent with the rules of Ethical and Professional Code of the Polish Psychological Association. Participation in the study was voluntary. Each subject was assessed during two individual meetings, held at a university facility or at home (at the subjects' request), with no assistance of family members. Data related to CR were collected during the first meeting, and the cognitive tests and BDI II were performed during the second meeting.

\section{Results}

Statistical analyses were performed using SPSS version 24. At the first stage, the method of k-means clustering was applied and the subjects' scores in the cognitive tasks (WAIS subtests, verbal fluency, MoCA) were divided into two clusters corresponding to higher and lower cognitive level (HCL and LCL, respectively). Results of these groups were compared relative to demographic and clinical data as well as CR. The related analyses were performed using Student's $t$ test for quantitative data with normal distribution (based on the results of ShapiroWilk test); additionally, effect size (Cohen's $d$ ) was calculated. Relationships between the level of cognitive competences and the qualitative variables were 
assessed using Pearson's $\chi^{2}$ test. Ultimately, forward selection method was applied to calculate logistic regression with interaction effect; additionally, odds ratios $(O R)$ were computed, independent variables being age, CR level, cardiovascular status (hypertension / no hypertension), depression intensity, and dependent variable being the level of cognitive competences (coded as follows - lower level: $\mathrm{LCL}=1$, and higher level: $\mathrm{HCL}=0$ ). The differences in $\mathrm{CR}$ were examined in relation to gender and cardiovascular status, and correlations (Pearson's $r$ ) were calculated for CR and age and depression level.

The characteristics of higher cognitive level $(\mathrm{HCL}, N=52)$ and lower cognitive level (LCL, $N=68$ ) groups are shown in Table 1 . The LCL subjects were significantly older than the HCL subjects; they acquired higher scores related to depressive mood, corresponding to depressive mood, and lower CR index. The strengths of relationships (Cohen's $d$ ) between the subjects' classification into the groups and the results are high. Health and occupational status are related to the groups: the unemployed/retired individuals as well as those with hypertension constituted a majority in the LCL group. No differences were observed in selfperceived executive difficulties (DEX-S) - low scores (low sense of executive deficits) were found in both groups.

Table 1

Characteristics and Comparison of Higher Cognitive Level (HCL) and Lower Cognitive Level (LCL) Groups

\begin{tabular}{|c|c|c|c|c|c|}
\hline \multirow{2}{*}{ Factors } & \multicolumn{2}{|c|}{$\operatorname{LCL}(N=68)$} & \multicolumn{2}{|c|}{$\operatorname{HCL}(N=52)$} & \multirow{2}{*}{$\begin{array}{l}\text { Student's } t \text {-test } \\
(p) / \text { Cohen's } d\end{array}$} \\
\hline & M & $(S D)$ & M & $(S D)$ & \\
\hline Age & 61.50 & $(11.29)$ & 52.07 & $(6.15)$ & $-5.84^{* * *} / 1.04$ \\
\hline Digits forward & 5.52 & $(1.90)$ & 6.80 & $(1.70)$ & $3.88^{* * *} / 0.70$ \\
\hline Digits backward & 4.89 & (1.86) & 6.07 & $(2.07)$ & $3.27^{* * *} / 0.60$ \\
\hline Vocabulary & 34.15 & $(13.36)$ & 52.25 & $(11.00)$ & $7.92^{* * *} / 1.48$ \\
\hline $\begin{array}{l}\text { Verbal fluency } \\
\text { (total of } 5 \text { tasks) }\end{array}$ & 59.58 & $(14.27)$ & 99.34 & $(16.50)$ & $14.21^{* * *} / 2.58$ \\
\hline $\mathrm{MoCA}$ & 24.90 & $(3.90)$ & 27.48 & $(2.29)$ & $4.09^{* * *} / 0.80$ \\
\hline BDI II & 13.57 & $(8.60)$ & 7.73 & $(5.90)$ & $-4.19^{* * *} / 0.80$ \\
\hline $\mathrm{DEX}-\mathrm{S}$ & 20.31 & $(10.20)$ & 18.34 & $(11.23)$ & $-1.00(.32) \mathrm{ns}$ \\
\hline Cognitive reserve (CR) & 19.73 & $(4.40)$ & 23.59 & $(4.30)$ & $4.78^{* * *} / 0.90$ \\
\hline Demographic variables & & $(\%)$ & & $(\%)$ & $\begin{array}{c}\text { Pearson's } \chi^{2} \\
\text { test with Yates' } \\
\text { correction }\end{array}$ \\
\hline \multicolumn{6}{|l|}{ Gender } \\
\hline Female & \multirow{2}{*}{\multicolumn{2}{|c|}{$\begin{array}{ll}43 & (63.2) \\
25 & (36.8)\end{array}$}} & \multirow{2}{*}{\multicolumn{2}{|c|}{$\begin{array}{ll}32 & (61.5) \\
20 & (38.5) \\
\end{array}$}} & $0.04(.85) \mathrm{ns}$ \\
\hline Male & & & & & \\
\hline \multicolumn{6}{|l|}{ Hypertension } \\
\hline No & \multirow{2}{*}{\multicolumn{2}{|c|}{$\begin{array}{l}19(27.9) \\
49(72.1)\end{array}$}} & \multirow{2}{*}{\multicolumn{2}{|c|}{$\begin{array}{ll}29 & (55.7) \\
23 & (44.3)\end{array}$}} & $9.51^{* * *}$ \\
\hline Yes & & & & & \\
\hline
\end{tabular}




\begin{tabular}{lrrr}
\hline Demographic variables & $N(\%)$ & $N(\%)$ & $\begin{array}{c}\text { Pearson's } \chi^{2} \\
\text { test with Yates' } \\
\text { correction }\end{array}$ \\
\hline Occupational activity & $35(51.4)$ & $7(13.5)$ & $18.71^{* * *}$ \\
$\quad$ Unemployed/retired & $33(49.6)$ & $45(86.5)$ & \\
$\quad$ Professionally active & $7(10.3)$ & $3 \quad(5.8)$ & $1.44(.48) \mathrm{ns}$ \\
\hline Marital status & $58(85.3)$ & $48(92.3)$ & \\
$\quad$ Widowed & $3(4.4)$ & $1 \quad(1.9)$ & \\
$\quad$ Married & & & \\
Divorced & & & \\
\hline
\end{tabular}

Note: ${ }^{* * *} p \leq .001 ; \mathrm{ns}-$ statistically insignificant difference/correlation.

\section{Predictors of Cognitive Performance}

The first goal of this study was to investigate whether level of CR, intensity of depression, age and health status are predictors of cognitive competences in adults. It was hypothesised that lower CR would significantly predict lower level of cognitive functions. Logistic regression with interaction effect was computed, independent variables being age, CR level, depression intensity (quantitative variables) as well as cardiovascular status (hypertension: no - yes), and dependent variable being the level of cognitive competences (higher, lower). The data are presented in Table 2. A likelihood of lower scores in cognitive tasks is approximately $14 \%$ lower in the subjects with higher CR $(O R<1 ; B=-.14)$. The risk of cognitive difficulties increases by approximately $0.09 \%$ with age in the subjects with lower $\mathrm{CR}(O R>1 ; B=.09)$. The findings showed no interaction between $\mathrm{CR}$ and age ( $p=$ .9). The other variables (depression intensity and cardiovascular status) were found to be insignificant and were excluded from the model. The model presents good parameters (sensitivity $=72 \%$, specificity $=67 \%$, accuracy $=70 \%$ ), yet it is more efficient in classifying the individuals at risk of cognitive deficits compared to those not at risk.

Table 2

Multivariate Logistic Regression Model (Forward Selection of Likelihood Ratio), and Odds Ratio (OR) for the Level of Cognitive Functioning (Encoded as Follows: $L C L=1, H C L=0$ )

\begin{tabular}{lccccc}
\hline Factors & $B$ & Wald $(Z)$ & $\begin{array}{c}O R \\
\operatorname{Exp}(B)\end{array}$ & $95 \% \mathrm{CI}$ & $p$ \\
\hline Cognitive reserve (CR) & -.14 & 7.74 & 0.86 & $<.78-.96>$ & $<.01$ \\
\hline Age & .09 & 12.04 & 1.09 & $<1.04-1.15>$ & $\leq .001$ \\
\hline
\end{tabular}

Note. $O R=$ odds ratio; $\mathrm{Cl}=$ confidence interval; $\chi^{2}$ for the model $36.13 p=.001 ;-2$ logarithm of likelihood $=131.08 ; R^{2}$ Cox \& Snell $=.26 ; R^{2}$ Nagelkerke $=.35 ; \chi^{2}$ Hosmer and Lemeshow test $=9.05, p=.3$; percentage of correct classifications 70 . 


\section{Relationships between CR and Gender Differences, Hypertension, Depression and Age}

The analyses were also designed to identify relationships between CR and gender, health status, intensity of depression and age.

$C R$ and Gender Differences. All the results of the women $(N=75)$ and men $(N$ $=45$ ) were compared. No differences were shown in relation to age and in the results of cognitive tasks and BDI-II $(p \geq .05)$, yet the men $(M=22.9, S D=4.7)$ differed from the women $(M=20.5, S D=4.7)$ in the value of $\mathrm{CR}(t=-2.6, p<.05)$. This effect was also significant in the HCL group $(t=-2.0, p<.01)$, where the CR index was higher in the men $(M=25.6, S D=4.2)$ than in the women $(M=22.3, S D=3.8)$, while in the LCL group no statistically significant differences $(t=-1.19, p \geq .05)$ were observed between the women $(M=19.2, S D=4.8)$ and the men $(M=20.6, S D$ $=3.6$ ).

Relationships between Health Status, $C R$ and Cognitive Functioning. The subjects with hypertension (HTN) did not differ in terms of CR $(M=20.8, S D=4.8)$ from the healthy $(\mathrm{H})$ individuals $(M=22.4, S D=4.6, t=-1.93, p \geq .05)$. Also, they achieved comparable to healthy results in Digit Span Forward $\left(M_{\mathrm{HTN}}=5.91, S D=\right.$ $\left.1.89 ; M_{\mathrm{H}}=6.35, S D=1.94 ; t=1.22, p \geq .05\right)$ and in DEX-S $\left(M_{\mathrm{HTN}}=20.5, S D=\right.$ $\left.10.55 ; M_{\mathrm{H}}=17.89, S D=10.75 ; t=-1.31, p \geq .05\right)$. On the other hand, their scores were lower in the verbal fluency tests $\left(M_{\mathrm{HTN}}=69.45, S D=21.59 ; M_{\mathrm{H}}=87.85, S D=\right.$ $25.91 ; t=4.22, p \leq .001)$, Digit Span Backwards $\left(M_{\mathrm{HTN}}=4.93, S D=1.46 ; M_{\mathrm{H}}=6.12\right.$, $S D=2.52 ; t=3.27, p \leq .01)$, and in MoCA test $\left(M_{\mathrm{HTN}}=25.16, S D=3.77 ; M_{\mathrm{H}}=\right.$ 27.39, $S D=2.68 ; t=3.77, p \leq .001)$, and higher in BDI II $\left(M_{\mathrm{HTN}}=12.55, S D=8.16\right.$; $\left.M_{\mathrm{H}}=8.77, S D=7.45 ; t=-2.57, p \leq .05\right)$.

$C R$, Depression and Age. The findings show a significant correlation $(r=-.44$, $p \leq .001)$ between depression intensity and CR: a higher level of CR is related to decreased intensity of depressive mood. Furthermore, the level of CR decreases with age $(r=-.38, p \leq .001)$, and the strength of the relationship is higher in HCL ( $r=-$ $.36, p \leq .005)$ than in LCL $(r=-.21, p \leq .05)$. Moreover, a higher level of depression is associated with poorer performance in Digit Span Forwards $(r=-.31, p \leq .001)$, Digit Span Backwards $(r=-.36, p \leq .001)$, Vocabulary $(r=-.44, p \leq .001)$, MoCA $(r$ $=-.54, p \leq .001)$ and verbal fluency $(r=-.46, p \leq .001)$.

\section{Discussion}

The current study was mainly designed to determine whether level of CR, intensity of depression, age and health status may be recognised as predictors of cognitive competences in adults. 


\section{Predictors of Cognitive Performance}

Based on earlier research findings it was anticipated that the lower level of CR would predict poorer cognitive capacities in adult Poles. The results of logistic regression analysis showed that higher CR decreases the likelihood of poorer scores achieved in cognitive tests by adults. This result is consistent with studies which reported higher $\mathrm{CR}$ in individuals with better overall cognitive efficiency assessed using screening methods (MoCA, Mini-Mental State Examination - MMSE) (Kang et al., 2018), and in subjects with higher abilities in various cognitive domains, e.g., memory (Frankenmolen et al., 2018), as well as visuospatial and executive functions (Roldán-Tapia et al., 2012; Roldán-Tapia et al., 2017). This positive association was found even though the studies applied a variety of CR indicators, such as isolated factors, e.g., leisure activity (Mella et al., 2017), years of education (Farfel et al., 2013; Roldán-Tapia et al., 2017), professional activity (Adam et al., 2013), intellectual and physical activity (Blondell et al., 2014; Cheng, 2016), community involvement (Amieva et al., 2010; Di Napoli et al., 2014; James, Wilson, Barnes, \& Bennett, 2011; Scarmeas, \& Stern, 2003), or indexes or summary scores acquired in various questionnaires (Grotz et al., 2017; Nucci et al., 2012; Opdebeeck et al., 2016; Pinto \& Tandel, 2016). Furthermore, lower level of CR is associated with lower cognitive efficiency in healthy adults (Corral et al., 2006).

Although it is optimistic, the findings should be approached with caution. Longitudinal studies showed that higher CR corresponds to faster cognitive decline in subjects with $\mathrm{AD}$, or more rapid conversion of MCI into $\mathrm{AD}$ (Andel et al., 2006; Soldan et al., 2017). This is because higher CR allows to cover up difficulties owing to effective compensatory mechanisms; however, once these are exhausted, expression of the deficits is clearly visible (Stern, 2002, 2003, 2009; Weiler et al., 2018). Hence, the level of CR reflects abilities acquired previously, giving shape to current cognitive performance rather than predicting the related capacities in the future (Tucker-Drob et al., 2009).

It was shown that age was a CR-independent factor contributing to the development of cognitive difficulties. The likelihood of cognitive efficiency deterioration is not high (odds ratio $\approx 1$ ), but the findings suggest that negative effects of age in cognitive efficiency may predominantly be manifested in the group with lower level of CR. Cognitive decline is a natural aspect of ageing, but, being heterogeneous in nature, it may depend on the level of CR (Corral et al., 2006; Tucker-Drob et al., 2009; Zaninotto et al., 2018; Zihl et al., 2014). In summary, the result of the regression analysis indicates that people with a higher level of CR better cope with cognitive ageing than people with a lower CR.

Both predictors of cognitive efficiency, i.e., $\mathrm{CR}$ and age jointly explain from 26 $\%\left(R_{\text {Cox \& Snell }}^{2}=.26\right)$ to $35 \%\left(R_{\text {Nagelkerke }}^{2}=.35\right)$ of the variance in the dependent variable, i.e., the level of cognitive efficiency. These findings and the lack of age $\mathrm{x}$ $\mathrm{CR}$ interaction in the regression analysis may be explained by the presence of latent 
factors (gender, level of depression, health status) or their relationships, which were not discussed in the classic single-factor CR model (Stern, 2002, 2003, 2009), but are considered in more recent research (Jones et al., 2011). For example, Satz, Cole, Hardy, \& Rassovsky (2011) proposed a four-factor model suggesting that CR comprises social and cognitive experiences and activity (education, social network, intellectual activity), yet these rely on other components of CR, i.e., overall intelligence, cognitive competences (attention, psychomotor speed) and efficiency of executive functions. A higher level of these, in turn, contributes to various forms of activity, consequently increasing the CR level (Puente, Lindbergh, \& Miller, 2015). Recognising that $\mathrm{CR}$, in addition to life activities, also includes intellectual competences usually treated as an effect of CR, may lead to a modified understanding of cause-and-effect relationships and new methodological approaches, particularly in longitudinal studies.

\section{Relationships between CR and Gender Differences, Hypertension, Depression and Age}

In the light of the above considerations, very interesting results are derived from correlation analyses showing a negative relationship between age and CR, i.e., CR decreases with age. This may suggest that the older participants' life activity is indeed decreasing, or this may be only their subjective opinion, or perhaps they do not remember many episodes from their own lives. This effect was found in the whole group and mainly in the HCL group, which may suggest that critical assessment of one's activity is linked to better cognitive efficiency (Grotz et al., 2017).

Correlation analyses showed that the intensity of a depressive mood decreases with higher levels of CR. According to the result of multivariate logistic regression, depression intensity as a sole factor, or in interaction with other variables, was not a predictor for cognitive function level. This result may be linked with the fact that the subjects in this study group were found with only mild depression. However, many studies have discussed the relations between CR, cognitive difficulties and depression. Depression promotes cognitive difficulties, and a depressive mood may be caused by cognitive deficits (Brailean et al., 2016). The higher CR mitigates the intensity of depression, as a result contributing to the stability of cognitive capacities (Lee, Park, \& Chey, 2018). Individuals with higher CR, predominantly characterised by positive affectivity, can regulate their emotions more effectively; on the other hand, lower CR is linked to negative mood and poorer cognitive efficiency (Bruno, Brown, Kapucu, Marmar, \& Pomara, 2014). Moreover, data from another study showed that depression mediates the links between CR and the cognitive functions, reducing the positive impact of CR (Szepietowska, 2019). Depression may also lead to negative assessment of selected aspects of $\mathrm{CR}$, e.g., social relations, which has also been confirmed by correlation analyses. 
Similarly, the present study failed to produce evidence showing that hypertension is a significant predictor of cognitive performance. However, it was demonstrated that the subjects with hypertension obtained poorer scores in some cognitive tasks. Hypertension adversely affects brain reserve (Alipour \& Goldust, 2016; Giordano et al., 2012) due to impaired perfusion as well as white matter atrophy in frontal, temporal, and parietal lobes (Novak \& Hajjar, 2010), pathology which leads to a decrease in cognitive capacities and an increase of depressive mood (Dufouil, Alperovitch, \& Tzourio, 2003). This effect does not have to be strong in individuals with hypertension who are under pharmacologic treatment, which explains the results of regression analysis.

Higher CR was found in the men compared to the women, and the effect was observed in the whole group and in the HCL group, but not in the LCL group. No gender-related differences were shown in the scores in the cognitive tests. A higher $\mathrm{CR}$ in men, and lower in women may result from different lifestyle preferences and gender roles (e.g., women giving up education to raise children). A similar result was reported by Nucci et al. (2012). Moreover, findings of numerous studies show that gender in interaction with other (biological and psychosocial) variables significantly modifies cognitive functioning (Gur \& Gur, 2002; Singh-Manoux et al., 2011). Cognitive decline occurs earlier in men, due to greater prevalence of metabolic disorders among them (Gur \& Gur, 2002; Zaninotto et al., 2018), yet women are in the risk group for AD (Laws et al., 2016) and depression (Lee et al., 2018). A tenyear longitudinal study (Singh-Manoux et al., 2011) showed gender-related differences in cognitive functions even in the initial measurement, while CR (e.g., education, professional status) explained $13-26 \%$ of the variance in results obtained by men, and $10-43 \%$ in the case of women. However, the association between CR and the trajectory of cognitive functioning was the same in both genders. It would be worthwhile to take this factor into account in further studies.

\section{Cognitive Reserve: Critical Evaluation of the Methodology}

The findings of the present study are relevant for the discussion focusing on the related models and indicators as well as the role of CR in shaping cognitive efficiency in adulthood and at old age. Cognitive reserve is built from early stages of development and is determined by interactions of various components, including genetic factors. Measurement of CR poses considerable difficulties. Researchers apply various CR indicators, e.g. quantitative, objective data (e.g., years of education) and/or qualitative data (e.g., type of responsibility at work). Assessment of certain data comprised in CR is performed by study participants in a retrospective and subjective manner (Grotz et al., 2017; Szepietowska, 2019), as a result of which the accumulated data may be inaccurate; additionally, the relevant questionnaires do not account for early stages of development and specificity of socio-political circumstances. As an example, the Working Activity subscale in the CRIq (Nucci et al., 2012) distinguishes a few levels of intellectual involvement in work (including 
e.g. jobs requiring low qualifications), frequently failing to reflect high requirements and training necessary for performing certain tasks. One example is the job of a caregiver, a function which in Poland should be performed by a person with at least secondary or higher education. Given the above, the present study proposed a modified method for calculating CR (i.e., the CR indicators applied included both self-report and objective data - level of education, professional activity). Research findings also showed associations between CR and gender, depression intensity and age. These results suggest that the individual variables mediate or moderate the relation between CR - cognitive functions (Szepietowska, 2019).

\section{Conclusion}

Attention to the effect of $\mathrm{CR}$ in cognitive functioning later in life is associated with efforts to find effective strategies to support satisfying ageing, a problem faced by numerous societies (Daffner, 2010; Le Carret et al., 2005; Tucker-Drob et al., 2009). By referring to earlier clinical observations (Blessed et al., 1968; Katzman et al., 1988), the CR construct tries to explain the impact of lifestyle, and its various aspects, on cognitive functioning at later stages of life (Stern, 2002, 2003, 2009, 2012; Tucker \& Stern, 2011).

Although the association between CR and current cognitive capacities has been shown, there are no grounds for predicting cognitive efficiency in subsequent years of life. Longitudinal studies, involving large cohorts, would be necessary to verify the hypothesis about the protective effects of higher CR. It has been suggested that CR resources may be enhanced at a later age (Satz et al., 2011). From the viewpoint of cognitive functioning, positive effects are achieved through various forms of cognitive stimulation (Thow et al., 2018), physical activity (Cheng, 2016), as well as by preventing metabolic disorders or withdrawal from social activity (Di Napoli et al., 2014; James et al., 2011), and by treatment of depression (Middleton \& Yaffe, 2009) in adults, even after 50 years of age.

In summary, it is necessary to emphasise limitations of the current study, i.e., the small size of the cohort, uneven representation of both genders in the group, and lack of longitudinal measurements. Despite these, we can conclude that age-related cognitive decline is more typical for individuals with lower level of CR and that higher CR decreases a likelihood of lower scores in cognitive tasks at present, but does not allow us to predict the trajectory of ageing in subsequent years of life.

\section{References}

Adam, S., Bonsang, E., Grotz, E., \& Perelman, S. (2013). Occupational activity and cognitive reserve: Implications in terms of prevention of cognitive aging and Alzheimer's disease. Clinical Interventions in Aging, 8, 377-390. doi:10.2147/CIA.S39921 
Alipour, H., \& Goldust, M. (2015). The association between blood pressure components and cognitive functions and cognitive reserve. Clinical and Experimental Hypertension, 38(1), 95-99. doi:10.3109/10641963.2015.1047946

Amieva, H., Stoykova, R., Matharan, F., Helmer, C., Antonucci, T. C., \& Dartigues, J. F. (2010). What aspects of social network are protective for dementia? Not the quantity but the quality of social interactions is protective up to 15 years later. Psychosomatic Medicine, 72(9), 905-911. doi:10.1097/PSY.0b013e3181f5e121

Andel, R., Vigen, C., Mack, W., Clark, L. J., \& Gatz, M. (2006). The effect of education and occupational complexity on rate of cognitive decline in Alzheimer's patients. Journal of International Neuropsychological Society, 12, 147-152. doi:10.1017/ S1355617706060206

Beck, A. T., Steer, R. A., \& Brown, G. (2019). BDI-II. Podręcznik [BDI-II. Mannual]. Warszawa: Pracownia Testów Psychologicznych PTP.

Blessed, G., Tomlinson, B., \& Roth, M. (1968). The association between quantitative measures of dementia and of senile change in the cerebral grey matter of elderly subjects. British Journal of Psychiatry, 114, 797-811. doi:10.1192/bjp.114.512.797

Blondell, S., Hammersley-Mather, R., \& Veerman, L. (2014). Does physical activity prevent cognitive decline and dementia? A systematic review and meta-analysis of longitudinal studies. BMC Public Health, 14, 510. http://www.biomedcentral.com/1471-2458/ $14 / 510$

Brailean, A., Comijs, H., Aartsen, M., Prince, M., Prina, M., Beekman, M., \& Huisman, M. (2016). Late-life depression symptom dimensions and cognitive functioning in the Longitudinal Aging Study Amsterdam (LASA). Journal of Affective Disorders, 201, 171-178. doi:10.1016/j.jad.2016.05.027

Bruno, D., Brown, A., Kapucu, A., Marmar, Ch., \& Pomara, N. (2014). Cognitive reserve and emotional stimuli in older individuals: Level of education moderates the age-related positivity effect. Experimental Aging Research, 40(2), 208-223. doi:10.1080/ 0361073X.2014.882212

Brzeziński, J., Gaul, M., Hornowska, E., Jaworowska, A., Machowski, A., \& Zakrzewska, M. (2004). Skala Inteligencji D. Wechslera dla Dorostych. Wersja zrewidowanarenormalizacja WAIS-R (PL) [D. Wechsler Intelligence Scale for Adults. Revised version - WAIS-R renormalization $(P L)]$. Warszawa: Pracownia Testów Psychologicznych Polskiego Towarzystwa Psychologicznego.

Butters, M., Young, J., Lopez, O., Aizenstein, H. J., Mulsant, B. H, Reynolds, C. F. 3rd, ... Becker, J. T. (2008). Pathways linking late-life depression to persistent cognitive impairment and dementia. Dialogues in Clinical Neuroscience, 10(3), 345-357.

Cheng, S. T. (2016). Cognitive reserve and the prevention of dementia: The role of physical and cognitive activities. Current Psychiatry Reports, 18(9), 85. doi:10.1007/s11920016-0721-2 
Clare, L., Wu, Y., Teale, J., MacLeod, C., Matthews, F., Brayne, C., \& Woods, B. (2017). Potentially modifiable lifestyle factors, cognitive reserve, and cognitive function in later life: A cross-sectional study. PLoS Medicine, 14(3), e1002259. doi:10.1371/journal. pmed.1002259

Corral, M., Rodriguez, M., Amenedo, E., Sanchez, J., \& Diaz, R. (2006). Cognitive reserve, age, and neuropsychological performance in healthy participants. Developmental Neuropsychology, 29(3), 479-491. doi:10.1207/s15326942dn2903_6

Daffner, K. (2010). Promoting successful cognitive aging: A Comprehensive Review. Journal of Alzheimers Disease, 19(4), 1101-1122. doi:10.3233/JAD-2010-1306

Długosz, Z. (2011). Population ageing in Europe. Procedia Social and Behavioral Sciences, 19, 47-55. doi:10.1016/j.sbspro.2011.05.106

Dufouil, C., Alperovitch, A., \& Tzourio, C. (2003). Influence of education on the relationship between white matter lesions and cognition. Neurology, 60(5), 831-836. doi:10.1212/01.wnl.0000049456.33231.96

Di Napoli, E., Wu, B., \& Scogin, F. (2014). Social isolation and cognitive function in Appalachian older adults. Research on Aging, 36(2), 161-179. doi:10.1177/ 0164027512470704

Farfel, J. M., Nitrini, R., Suemoto, C. K., Grinberg, L. T., Ferretti, R. E. L., Leite, R. E. P., ... On behalf of the Brazilian Aging Brain Study Group (2013). Very low levels of education and cognitive reserve: A clinicopathologic study. Neurology, 81(7), 650-657. doi:10.1212/WNL.0b013e3182a08f1b

Ferreira, D., Machado, A., Molina, Y., Nieto, A., Correia, R., Westman, E., \& Barroso, J. (2017). Cognitive variability during middle-age: Possible association with neurodegeneration and cognitive reserve. Frontiers in Aging Neuroscience, 9, 188. doi:10.3389/fnagi.2017.00188

Frankenmolen, N., Fasotti, L., Kessels, R., \& Oosterman, J. (2018). The influence of cognitive reserve and age on the use of memory strategies. Experimental Aging Research, 44(2), 117-134. doi:10.1080/0361073X.2017.1422472

Giordano, N., Tikhonoff, V., Palatini, P., Bascelli, A., Boschetti, G., De Lazzari, F., ... Casiglia, E. (2012). Cognitive functions and cognitive reserve in relation to blood pressure components in a population-based cohort aged 53 to 94 years. International Journal of Hypertension, 274851. doi:10.1155/2012/274851

Grotz, C., Seron, X., Van Wissen, M., \& Adam, S. (2017). How should proxies of cognitive reserve be evaluated in a population of healthy older adults? International Psychogeriatrics, 29(1), 123-136. doi:10.1017/S1041610216001745

Gur, R. E., \& Gur, R. C. (2002). Gender differences in aging: Cognition, emotions, and neuroimaging studies. Dialogues in Clinical Neuroscience, 4(2), 197-210.

James, B. D., Wilson, R. S., Barnes, L. L., \& Bennett, D. A. (2011). Late-life social activity and cognitive decline in old age. Journal of International Neuropsychological Society, 17(6), 998-1005. doi:10.1017/S1355617711000531 
Jones, R., Manly, J., Glymour, M., Rentz, D., Jefferson, A., \& Stern, Y. (2011). Conceptual and measurement challenges in research on cognitive reserve. Journal of International Neuropsychological Society, 17(4), 593-601. doi:10.1017/S1355617710001748

Kang, J. M., Cho, Y. S., Park, S., Lee, B. H., Sohn, B. K., Choi, C. H., ... Lee, J. Y. (2018). Montreal cognitive assessment reflects cognitive reserve. BMC Geriatrics, 18(1), 261. doi:10.1186/s12877-018-0951-8

Katzman, R., Terry, R., DeTeresa, R., Brown, T., Davies, P., Fuld, P., Renbing, X., \& Peck, A. (1988). Clinical, pathological, and neurochemical changes in dementia: A subgroup with preserved mental status and numerous neocortical plaques. Annals of Neurology, 23(2), 138-144. doi:10.1002/ana.410230206

Knäuper, B., Carriere, K., Chamandy, M., Xu, Z., Schwarz, N., \& Rosen, N. (2016). How aging affects self-reports. European Journal of Ageing, 13, 185-193. doi:10.1007/ s10433-016-0369-0

Laws, K. R., Irvine, K., \& Gale, T. M. (2016). Sex differences in cognitive impairment in Alzheimer's disease. World Journal of Psychiatry, 6(1), 54-65. doi:10.5498/wjp. v6.i1.54

Le Carret, N., Auriacombe, S., Letenneur, L., Bergua, V., Dartigues, J. F., \& Fabrigoule, C. (2005). Influence of education on the pattern of cognitive deterioration in AD patients: The cognitive reserve hypothesis. Brain and Cognition, 57, 120-126. doi:10.1016/j. bandc.2004.08.031

Lee, J., Park, H., \& Chey, J. (2018). Education as a protective factor moderating the effect of depression on memory impairment in elderly women. Psychiatry Investigation, 15(1), 70-77. doi:10.4306/pi.2018.15.1.70

León, I., García-García, J., \& Roldán-Tapia, L. (2014). Estimating cognitive reserve in healthy adults using the cognitive reserve scale. PLOS ONE, 9(7), e102632. doi:10.1371/ journal.pone.0102632

Marques, P., Moreira, P., Magalhaes, R., Costa, P., Santos, N., Zihl, J., ... Sousa, N. (2016). The functional connectome of cognitive reserve. Human Brain Mapping, 37, 33103322. doi:10.1002/hbm.23242

Mella, N., Grob, E., Döll, S., Ghisletta, P., \& de Ribaupierre, A. (2017). Leisure activities and change in cognitive stability: A multivariate approach. Brain Sciences, 7, 27. doi:10.3390/brainsci7030027

Middleton, L., \& Yaffe, K. (2009). Promising strategies for the prevention of dementia. Archives of Neurology, 66(10), 1210-1215. doi:10.1001/archneurol.2009.201

Mondini, S., Guarino, R., Jarema, G., Kehayia, E., Nair, V., Nucci, M., \& Mapelli, D. (2014). Cognitive reserve in a cross-cultural population: The case of Italian emigrants in Montreal. Aging Clinical and Experimental Research, 26(6), 655-659. doi:10.1007/ s40520-014-0224-0 
Nasreddine, Z., Phillips, N., Bedirian, V., Charbonneau, S., Whitehead, V., Collin, I., ... Chertkow, H. (2005). The Montreal Cognitive Assessment, MoCA: A brief screening tool for mild cognitive impairment. Journal of the American Geriatrics Society, 53, 695699. doi:10.1111/j.1532-5415.2005.53221.x

Novak, V., \& Hajjar, I. (2010). The relationship between blood pressure and cognitive function. Nature Reviews Cardiology, 7(12), 686-698. doi:10.1038/nrcardio.2010.161

Nucci, M., Mapelli, D., \& Mondini, S. (2012). Cognitive Reserve index questionnaire (CRIq): A new instrument for measuring of cognitive reserve. Aging Clinical and Experimental Research, 24, 218-226. doi:10.3275/7800

Oakes, J. M., \& Rossi, P. H. (2003). The measurement of SES in health research: Current practice and steps toward a new approach. Social Science and Medicine, 56(4), 769-784. doi:10.1016/s0277-9536(02)00073-4

Olszewska, D., Lonergan, R., Fallon, E., \& Lynch, T. (2016). Genetics of frontotemporal dementia. Current Neurology and Neuroscience Report, 16, 107. doi:10.1007/s11910016-0707-9

Opdebeeck, C., Martyr, A., \& Clare, L. (2016). Cognitive reserve and cognitive function in healthy older people: A meta-analysis. Aging, Neuropsychology and Cognition, 23(1), 40-60. doi:10.1080/13825585.2015.1041450

Pettigrew, C., Soldan, A., Li, S., Lu, Y., Wang, M. C., Selnes, O. A., ... The Biocard Research Team (2013). Relationship of cognitive reserve and APOE status to the emergence of clinical symptoms in preclinical Alzheimer's disease. Cognitive Neuroscience, 4(3-4), 136-142. doi:10.1080/17588928.2013.831820

Pinto, Ch., \& Tandel, K. (2016). Cognitive reserve: Concept, determinants, and promotion. Journal of Geriatric Men Health, 3(1), 44-51. doi:10.4103/2348-9995.181916

Placek, K., Massimo, L., Olm, C., Ternes, K., Firn, K., Van Deerlin, V., \& McMillan, C. T. (2016). Cognitive reserve in frontotemporal degeneration: Neuroanatomic and neuropsychological evidence. Neurology, 87(17), 1813-1819. doi:10.1212/WNL. 0000000000003250

Prince, M., Bryce, R., Albanese, E., Wimo, A., Ribeiro, W., \& Ferri, C. (2013). The global prevalence of dementia: A systematic review and metaanalysis. Alzheimer's \& Dementia, 9, 63-75. doi:10.1016/j.jalz.2012.11.007

Puente, A., Lindbergh, C., \& Miller, S. (2015). The relationship between cognitive reserve and functional ability is mediated by executive functioning in older adults. The Clinical Neuropsychologist, 29(1), 67-81. doi:10.1080/13854046.2015.1005676

Rami, L., Valls-Pedret, C., Bartres-Faz, D., Caprile, C., Sole-Padulles, C., Castellvi, M., ... Molinuevo, J. (2011). Cognitive reserve questionnaire. Scores obtained in a healthy elderly population and in one with Alzheimer's disease. Revista de Neurologia, 52, 195201.

Roldán-Tapia, L., García, J., Cánovas, R., \& León, I. (2012). Cognitive Reserve, age, and their relation to attentional and executive functions. Applied Neuropsychology: Adult, 19(1), 2-8. doi:10.1080/09084282.2011.595458 
Roldán-Tapia, M. D., Cánovas, R., León, C., \& García-Garcia, J. (2017). Cognitive vulnerability in aging may be modulated by education and reserve in healthy people. Frontiers in Aging Neuroscience, 9, 340. doi:10.3389/fnagi.2017.00340

Satz, P., Cole, M., Hardy, D., \& Rassovsky, Y. (2011). Brain and cognitive reserve: Mediator(s) and construct validity, a critique. Journal of Clinical and Experimental Neuropsychology, 33(1), 121-130. doi:10.1080/13803395.2010.493151

Scarmeas, N., \& Stern, Y. (2003). Cognitive reserve and lifestyle. Journal of Clinical and Experimental Neuropsychology, 25(5), 625-633. doi:10.1076/jcen.25.5.625.14576

Schweizer, T. A., Ware, J., Fischer, C. E., Craik, F. I., \& Bialystok, E. (2012). Bilingualism as a contributor to cognitive reserve: Evidence from brain atrophy in Alzheimer's disease. Cortex, 48, 991-996. doi:10.1016/j.cortex.2011.04.009

Serra, L., Musicco, M., Cercignani, M., Torso, M., Spanò, B., Mastropasqua, C., ... Bozzali, M. (2015). Cognitive reserve and the risk for Alzheimer's disease: A longitudinal study. Neurobiology of Aging, 36(2), 592-600. doi:10.1016/j.neurobiolaging.2014.10.010

Singh-Manoux, A., Marmot, M., Glymour, M., Sabia, S., Kivimäki, M., \& Dugravot, A. (2011). Does cognitive reserve shape cognitive decline? Annals of Neurology, 70(2), 296-304. doi:10.1002/ana.22391

Soldan, A., Pettigrew, C., Cai, Q., Wang, J., Wang, M., Moghekar, A., ... the BIOCARD Research Team (2017). Cognitive reserve and long-term change in cognition in aging and preclinical Alzheimer's disease. Neurobiology of Aging, 60, 164-172. doi:10.1016/j. neurobiolaging.2017.09.002

Strauss, E., Sherman, E. M., \& Spreen, O. (2006). A compendium of neuropsychological tests: Administration, norms, and commentary ( $3 r d$ ed.). New York: Oxford University Press.

Steffener, J., \& Stern, Y. (2012). Exploring the neural basis of cognitive reserve in aging. Biochimica et Biophysica Acta, 1822, 467-473. doi:10.1016/j.bbadis.2011.09.012

Stern, Y. (2002). What is cognitive reserve? Theory and research application of the reserve concept. Journal of International Neuropsychological Society, 8, 448-460. doi:10.1017/ S1355617702813248

Stern, Y. (2003). The concept of cognitive reserve: A catalyst for research. Journal of Clinical and Experimental Neuropsychology, 25(5), 589-593. doi:10.1076/jcen.25.5. 589.14571

Stern, Y. (2009). Cognitive reserve. Neuropsychologia, 47(10), 2015-2028. doi:10.1016/j. neuropsychologia.2009.03.004

Stern, Y. (2012). Cognitive reserve in ageing and Alzheimer's disease. Lancet Neurology, 11(11), 1006-1012. doi:10.1016/S1474-4422(12)70191-6

Szepietowska, E. (2019). Mediatory effect of depression in the relations between cognitive reserve and cognitive abilities. Does a CR index matter? Health Psychology Report, 7(3), 200-212. doi:10.5114/hpr.2019.87865

Thow, M. E., Summers, M. J., Saunders, N. L. Summers, J. J., Ritchie, K., \& Vickers, J. C. (2018). Further education improves cognitive reserve and triggers improvement in 
selective cognitive functions in older adults: The Tasmanian Healthy Brain Project. Alzheimers and Dementia, 10, 22-30. doi:10.1016/j.dadm.2017.08.004

Tucker-Drob, E., Johnson, K., \& Jones, R. (2009). The Cognitive reserve hypothesis: A longitudinal examination of age-associated declines in reasoning and processing speed. Developmental Psychology, 45(2), 431-446. doi:10.1037/a0014012

Tucker, A, \& Stern, Y. (2011). Cognitive reserve in aging. Current Alzheimer Research, 8(4), 354-360. doi:10.2174/156720511795745320

Weiler, M., Casseb, R., Machado de Campos, B., Vieira de Ligo Teixeira, C., Mac Knight Carletti-Cassani, A., Vicentini, J., ... Castellano, G. (2018). Cognitive reserve relates to functional network efficiency in Alzheimer's disease. Frontiers in Aging Neuroscience, 10, 255. doi:10.3389/fnagi.2018.00255

Wilson, B. A., Alderman, N., Burgess, P. W., Emslie, H., \& Evans, J. J. (1996). Behavioural assessment of the dysexecutive syndrome. Bury St. Edmunds: Thames Valley Test Company.

World Health Organization. (2015). World report on ageing and health. Switzerland: WHO Library Cataloguing-in-Publication Data.

Zaninotto, P., Batty, G. D., Allerhand, M., \& Deary, I. (2018). Cognitive function trajectories and their determinants in older people: 8 years of follow-up in the English Longitudinal Study of Ageing. Journal of Epidemiology and Community Health, 72(8), 685-694. doi:10.1136/jech-2017-210116

Zihl, J., Fink, Th., Pargent, F., Ziegler, M., \& Bühner, M. (2014). Cognitive reserve in young and old healthy subjects: Differences and similarities in a testing-the-limits paradigm with DSST. PLoS ONE, 9(1), e84590. doi:10.1371/journal.pone.0084590

\title{
Više razine kognitivne zalihe smanjuju rizik od kognitivnih poteškoća kod zdravih odraslih ispitanika
}

\begin{abstract}
Sažetak
Cilj je ovog istraživanja bio ispitati je li kod odraslih ispitanika kognitivna zaliha povezana s razinom kognitivne kompetencije. Rezultati brojnih prethodnih istraživanja uputili su na zaštitnu ulogu velike kognitivne zalihe, operacionalizirane prethodno usvojenim znanjem i stečenim iskustvom, za očuvanje kognitivnih kapaciteta odraslih i starijih ljudi. U skladu s time, hipoteza je ovog istraživanja bila da će manja kognitivna zaliha predviđati niže kognitivne sposobnosti u odrasloj dobi. U istraživanju je sudjelovalo 120 zdravih odraslih ispitanika iz Poljske (75 žena i 45 muškaraca) raspona dobi od 40 do 85 godina $(M=57.42 ; S D=10.48)$. Indeksom kognitivne zalihe obuhvaćena je razina formalnog obrazovanja, uključenost u socijalne, profesionalne i tjelesne aktivnosti te razina socijalne podrške. Također, prikupljeni su podaci koji se odnose na razine depresivnosti (Beckov inventar depresije) te kardiovaskularni status. Kognitivne kompetencije ispitanika ispitane su korištenjem Montrealske ljestvice kognitivne procjene, suptestova Wechslerova testa inteligencije za odrasle, testova verbalne fluentnosti i samoprocjenom izvršnih funkcija. Na temelju rezultata na testovima kognitivnih sposobnosti ispitanici su podijeljeni u skupine s nižom i s višom razinom
\end{abstract}


kognitivnog funkcioniranja. Ispitanici s nižom razinom kognitivnog funkcioniranja bili su stariji, imali su višu razinu depresivnosti i manje kognitivne zalihe u usporedbi s ispitanicima s višom razinom kognitivnog funkcioniranja. S ciljem ispitivanja jesu li manje kognitivne zalihe povezane $s$ nižim kognitivnim sposobnostima, provedena je logistička regresijska analiza. U obzir je pritom uzeta dob, kardiovaskularni status i razina depresivnosti ispitanika. Rezultati su pokazali da veća kognitivna zaliha smanjuje rizik od kognitivnih poteškoća. Starija dob povezana je sa slabijim kognitivnim funkcioniranjem, no nije dobivena interakcija kognitivne zalihe i dobi. Depresivnost i zdravstveni status nisu predviđali kognitivne sposobnosti. Dobiveni rezultati u skladu su s rezultatima prethodnih istraživanja: veća kognitivna zaliha može biti povezana s manjim rizikom od kognitivnih poteškoća, pri čemu se dob pokazuje kao varijabla koja je neovisna o kognitivnoj zalihi i koja utječe na izvedbu na kognitivnim zadacima, odnosno rizik od slabljenja kognitivnih funkcija povećava se s dobi. Dobiveni rezultati raspravljeni su u kontekstu modela i indeksa kognitivne zalihe.

Ključne riječi: kognitivna zaliha, odrasli i stariji ispitanici, kognitivno funkcioniranje

Primljeno: 13.7.2018. 